\title{
A representação do Diabo no conto $A$ Igreja do Diabo de Machado de Assis e no romance Grande Sertão: veredas de Guimarães Rosa
}

\author{
Ricardo Gomes da Silva
}

\section{SciELO Books / SciELO Livros / SciELO Libros}

SILVA, RG. A representação do Diabo no conto A Igreja do Diabo de Machado de Assis e no romance Grande Sertão: veredas de Guimarães Rosa. In MAGALHÃES, ACM., et al., orgs. $O$ demoníaco na literatura [online]. Campina Grande: EDUEPB, 2012. pp. 255-262. ISBN 978-857879-188-9. Available from SciELO Books <http://books.scielo.org $>$.

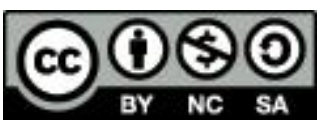

All the contents of this work, except where otherwise noted, is licensed under a Creative Commons Attribution-Non Commercial-ShareAlike 3.0 Unported.

Todo o conteúdo deste trabalho, exceto quando houver ressalva, é publicado sob a licença Creative Commons Atribuição Uso Não Comercial - Partilha nos Mesmos Termos 3.0 Não adaptada.

Todo el contenido de esta obra, excepto donde se indique lo contrario, está bajo licencia de la licencia Creative Commons Reconocimento-NoComercial-CompartirIgual 3.0 Unported. 


\title{
A representação do Diabo no conto $A$ Igreja do Diabo de Machado de Assis e no romance Grande Sertão: veredas de Guimarães Rosa.
}

\author{
Ricardo Gomes da Silva (UEL)
}

"Eu penso se o Diabo não existe, foi simplesmente criado pelo homem, este fez à sua imagem e semelhança."

Dostoiévski

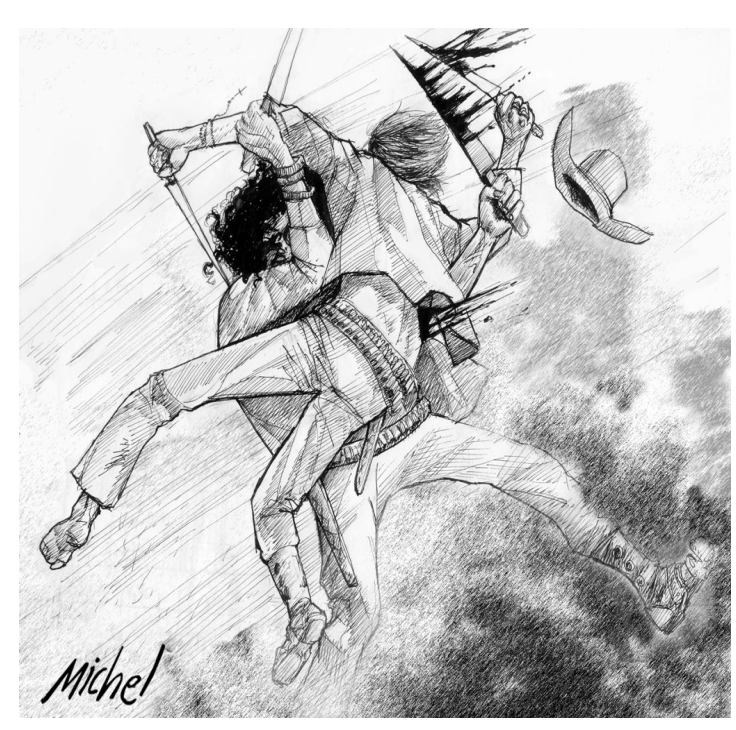

O Diabo ocupa um constante e importante lugar no imaginário da cultura ocidental. Não menos constante e importante é seu lugar na literatura, sobretudo durante e após a Idade Média. São tantas as representações do Diabo na literatura que podemos afirmar a existência de uma espécie de categoria dos personagens-diabo. "Categoria de personagem" e não simplesmente personagem, pois as representações do Diabo na literatura 
são as mais diversas possíveis. Quando se fala em Diabo não se fala de um personagem único, mas de um conceito a ser livremente desenvolvido. Dante em $A$ divina comédia desenha a sua maneira o Diabo, Milton em $O$ paraíso perdido o pinta de outra forma. Diferente será também o desenho do Diabo em O Fausto, de Goethe, ou Litanias de Satanás de Baudelaire, o mesmo se dará na obra de Shakespeare, de Thomas Mann, Paul Valéry, Walter Scott, Allan Poe, Gil Vicente, Fernando Pessoa, Saramago.

$\mathrm{Na}$ literatura brasileira os personagens-diabo estão presentes em diversas obras, e em especial em conhecidíssimas e marcantes narrativas de Machado de Assis e Guimarães Rosa, em A igreja do diabo e em Grande Sertão: Veredas. E assim como as tantas outras representações do Diabo, realizadas por diversos escritores, são diferentes uma da outra. Podemos dizer que personagem-diabo machadiano é tão diferente do rosiano ao ponto de ser oposto. Mas de que forma isto ocorre? De que maneira estes personagens-diabo são diferentes? Estes e outros pontos que concernem a questão oposição das figuras do diabo presentes em $A$ igreja do diabo e em Grande Sertão: Veredas nosso objetivo neste artigo.

Partimos, então, da definição do conceito de representação rumo à análise dos nossos objetos. O pensador francês Roger Chartier (2002) ao teorizar sobre o conceito de representação afirma que representar é criar uma imagem de algo, na qual haverá uma relação decifrável entre a imagem e o que ela significa. Em outros termos representar é criar signos que remetem a algo. As letras, sílabas e palavras que vemos nesta folha são representações de vocalizações verbais que foram construídas para representar ideias, objetos, lugares, pessoas, etc. Desta maneira a escrita é uma representação visual das palavras que por sua vez são representações verbais de coisas concretas e abstratas.

A literatura, por definição, está intrinsecamente envolvida nestas relações de representação. As discussões neste sentido são diversas e vêm desde Platão ${ }^{1}$ - ao condenar a poesia por se tratar de imitação - até os ideais dos escritores Realistas na busca da representação na literatura da realidade de forma mais impecável possível.

Desta forma podemos afirmar que o Diabo, enquanto uma entidade abstrata, é a representação de algo. Na realidade a ideia de Diabo nasce 
como uma representação para posteriormente ganhar status de entidade. Neste sentido a representação do Diabo na literatura se faz de forma extremamente complexa. Pois, na literatura acaba-se por representar a representação que se tem de uma entidade que por sua vez também representa algo. Para não nos perdemos nisto que mais parece um jogo de palavras façamos-nos duas perguntas básicas: O que o Diabo representa? Como o Diabo é representado?

Dizer apenas que o Diabo representa o mal seria simplificá-lo por demais. Neste sentido o livro O Diabo no imaginário Cristão nos fornece o panorama histórico necessário para compreendermos a estrutura da figura do Diabo. De acordo com NOGUEIRA (1986) na antiguidade não se tem registro de alguma figura que pudesse correlatamente representar o mal. Tratando-se de textos bíblicos, no Antigo Testamento a única contribuição que se tem a personificação do mal se encontra no Livro de Jó. O Anjo "Satã" - que significa aquele que acusa ou que calunia - levanta a suspeita perante o Senhor de que um de seus servos seria fiel por interesse. A partir do Novo Testamento passa-se a se evidenciar a existência de um ser como símbolo do mal. É quando surge o termo diabo, do grego Diabolos, que significa aquele que leva o juízo. Neste sentido, a passagem de Jesus no deserto sendo tentado pelo Diabo é uma das que mais contribuirão para formação desta personificação do mal.

Até a Idade Média se desenvolvem uma série de textos não canônicos acerca das Legiões de Demônios e do Apocalipse. Com o passar do tempo pensadores da Igreja Católica como Eusébio, Cipriano e Tertuliano começam a se preocupar e escrever sobre o Diabo. Tem-se então o que NOGUEIRA (1986) chama de Institucionalização do Diabo. É neste período que surgirá a tardia leitura da Serpente como um dos disfarces do Diabo. E como o Diabo passa a ser culpado pela Igreja por todas as desgraças, desde pestes a desastres naturais, começa-se a implantar o medo de sua figura. Contudo, a excessiva evidenciação da figura do Diabo faz com que ele cresça mais e mais no imaginário coletivo, transformando-o em uma gigantesca e assustadora criatura maligna.

A quase que onipresença e onipotência adquirida pelo Diabo neste período ao mesmo tempo em que farão com que ele arrebate uma multidão de tementes lhe renderão sociedades secretas de adoração. A evolução 
destas sociedades de adoração ao Diabo originará a imagem Moderna do Diabo. Assim o Diabo passa a simbolizar a negação a tirania de Deus. Satã será visto como símbolo de espírito livre em oposição à instituição religiosa cristã. Será também o diabo transformado em sinônimo de progresso, liberdade, ciência e anti-herói, o herói rebelde, o deprimente Anjo caído.

Quanto as representações do Diabo quem nos auxilia a pensar é Umberto Eco em dois subcapítulos de Historia de la fealdad intitulados Las metamorfosis del diablo e Del satanás rebelde al pobre Mefistófeles.

As metamorfoses do Diabo apresentadas e discutidas por Umberto Eco mostram como o modo que o diabo é representado está ligado às nuanças do que ele representa. Neste sentido o pensador italiano explica que embora o Diabo esteja ligado à maldade, nem sempre é descrito com aspectos monstruosos. Estando a imagem do Diabo ligada à calunia ou à sedução ele poderá ser representado com aspectos de feiúra reduzidos ou mesmo como uma belíssima mulher. Por vezes ainda que o Diabo é representado como uma criatura carnavalesca: alegre, dançante e divertida.

ECO (2007) vê nas representações do Diabo por Dante e Tasso a imagem de um ser majestoso. Em A matança dos inocentes (1632), de Marino, o Diabo é representado "como un ser sobre el que pesa una profunda tristeza, y que ello en cierto modo nos inspira piedad."(ECO, 2007, p.179). Em O Paraíso Perdido (1667) de Milton, o Diabo inspira de um "sentimiento de venganza y de afirmarción del propio Yo, pero sin duda un modelo de pura energia en rebelión" (ECO, 2007, p.179). Estas representações vão ao encontro com a adoração e aproximação do Diabo no mundo moderno notada por NOGUEIRA (1986).

O último estágio de metamorfose deste "ser" é o de "pobre diabo". De acordo com ECO (2007), estágio este iniciado por Goethe ao atribuir ao Diabo qualidades demasiadamente humanas. A imagem de Mefistófeles, um Diabo medíocre dotado da mesquinhez de um pequeno-burguês, será o modelo às representações de Dostoievski, Giovanni Papini e Thomas Mann.

Temos a partir de ECO (2007) e NOGUEIRA (1986) duas representações básicas e opostas do Diabo: Medieval X Moderna. O Diabo, 
sinônimo de maldade na Idade Média representou algo a se temer e respeitar. Já na Modernidade passou a representar algo a se identificar e se compadecer.

Esta base opositiva (temor e respeito $\mathrm{X}$ identificação e compadecimento) nos dá suporte para pensarmos no contraste dos personagens-diabo do conto A igreja do diabo de Machado de Assis e do romance Grande Sertão: Veredas de Guimarães Rosa. A oposição da representação do Diabo nestas duas obras pode ser pensada a partir da dicotomia de representações: Idade Média X Modernidade. A representação machadiana acompanha uma visão Moderna do Diabo, enquanto a representação rosiana está mais ligada ao viés Medieval.

Como é próprio das narrativas alegóricas (fábula, apólogo, parábola), em $A$ igreja do diabo são adotadas as premissas do Maravilhoso (vide a definição de TODOROV), onde os acontecimentos "sobrenaturais" não subvertem a verossimilhança interna, ou seja, não causam estranhamento. Não questionamos o fato de como esta história pode constar num manuscrito beneditino, quem a presenciou se ela demorou séculos, como foi possível alguém entender a língua que Deus e o Diabo conversam. Aceitamos a história sem nos questionarmos sobre isto, pois ao interpretamos uma narrativa alegórica procuramos apreender seu teor moralizante ou pedagógico.

O pacto em Fausto de Goethe possui também este viés alegórico. A aparição de Mefistófeles não entra em choque com as leis de verossimilhança internas da peça. O Diabo se metamorfoseia de cachorro em um distinto homem sem causar-nos estranhamento.

O alegórico nestas obras de Goethe e Machado concede ao Diabo voz, forma, existência e contornos quase humanos. Tudo isto contribuirá para a formação das imagens de pobres diabos que são. Decadentes e deprimentes ambas são representações Modernas do Diabo. O personagem-diabo machadiano de início lamenta com Deus: "Estou cansado da minha desorganização, do meu reinado casual e adventício. É tempo de obter a vitória final e completa.” (ASSIS, 1977, p.59). Ao final, após constatar a decadência de sua igreja, volta a Deus mais triste e frustrado do que no início. 
Da mesma forma, os ínfimos poderes de Mefistófeles de Goethe nos diálogos que ele trava com Fausto:

\section{FAUSTO}

Já sei o que és, e qual teu nobre empenho.

Como não podes destruir o todo, pões-te a tomar desforra em ninharias.

\section{MEFISTÓFELES}

Consigo pouco, é certo. O oposto ao Nada, O Que quer que é que existe, o mundo bronco, por mais que em vulnerá-lo me desvele, fica-me sempre ileso. Em vão lhe arrojo ondas, procelas, fogos, terremotos; ao cabo, terra e mar ficam serenos. Pois a relé nojosa, a corja humana! Não há meter-lhe dente. Ando, há que tempos, a matar neles, sem parar na faina, e a espécie a medrar sempre em sangue, em forças. É para endoidecer! De ar, água, e terra, do quente e frio, do húmido e do seco mil germes brotam... Se não pilho o fogo, ficava-me sem nada.

\section{FAUSTO}

E opões à força eterno-activa, criadora, amante. pobre demónio, o punho teu fechado! Busca outro ofício, aborto vil de caos. (GOETHE, 1949, p. 85-6)

Ou seja, tanto pelo viés alegórico de $A$ igreja do diabo, que nos permite aproxima-lo de trejeitos humanos, quanto pela própria figuração enquanto ser decadente, notamos mais similaridade desde personagemdiabo com a representação Moderna do que com a Medieval. Da mesma forma, o majestoso personagem-diabo Diabo de Grande Sertão: Veredas tem mais a ver com a representação Medieval. 
Um dos principais indícios do personagem-diabo rosiano se tratar de uma representação Medieval reside na questão do pacto. $\mathrm{O}$ receio que se tem em combater Hermógenes, uma vez que este tem pacto com o Diabo, é acima de tudo respeito e temor às supremas forças diabólicas. "Pactário ele era, se avezando por cima de todos."(ROSA,2001, p.424) diz Riobaldo acerca de Hermógenes.

O pacto, ou a tentativa de pacto, de Riobaldo será com o intuito de conseguir as forças equivalentes as de Hermógenes. A lógica deduzida é a seguinte: O Diabo é tão poderoso que só há uma maneira de vencer seus pactários, sendo também um.

Deus é lembrado por Riobaldo no momento do pacto, mas é nome do Diabo que ele grita: - "Ei, Lúcifer! Satanás, dos meus Infernos!" (ROSA, 2001,p.438). Riobaldo na incerteza do pacto pensa na imagem de Deus, mas em seguida percebe que somente o Diabo poderá lhe ajudar. O medo do Diabo em detrimento da fé em Deus nos remete as primeiras Sociedades Secretas de Adoração ao Satanás. Em um primeiro momento tais sociedades secretas consistiam numa estratégica maneira de se por ao lado do mais forte: assim como Riobaldo tenta fazer.

Outro indício que liga Grande Sertão: Veredas à representação Medieval do Diabo é a sua onipresença. Desde o subtítulo até as últimas linhas do romance o personagem-diabo está presente. O diabo parece ser uma das preocupações mais constantes de Riobaldo. Ele fala o tempo todo sobre o Diabo, sobre sua existência ou não. Talvez esta seja uma das preocupações mais constante de Riobaldo, por conta do medo de que se o Diabo realmente existir, signifique que sua alma foi mesmo vendida.

Nestas duas obras temos a sinterização das duas principais e opostas representações dos personagens-diabo: a Medieval e a Moderna. Temos o que podemos chamar, a partir de Eco e Nogueira, de uma Moderna representação do Diabo em $A$ igreja do diabo. A voz, as feições e as fraquezas humanas, que ao mesmo tempo aproximam a representação do Diabo de nós, o transforma num ser decadente. Oposta a esta representação do Diabo é a de Grande Sertão: Veredas na qual o Diabo se aproxima da sua imagem Medieval por figurar como imponente, temível, reinante sobre os homens. 


\section{Bibliografia}

ALMEIDA, Marcos Renato Holtz de. As metamorfoses do diabo: a secularização do mito e sua apropriação pela indústria cultural no século XX. Tese (Doutorado em Sociologia). UNESP,Araraquara. 2008.

ASSIS, Machado de. A igreja do diabo. In: Histórias sem data. Rio de Janeiro: Civilização Brasileira, 1977.

CHARTIER, Roger. À beira da falésia. A história entre certezas e inquietude. Porto Alegre: Editora Universidade UFRGS, 2002

ECO, Umberto. Historia de la fealdad. Barcelona: Ed. Mondadori, 2007

FERRAZ, Salma. O Diabo na literatura para crianças. Linguagens Revista de Letras, Artes e Comunicação. v. 1, n. 3, p. 220-238, set./dez. 2007.

GOETHE, Johann Wolfgang von. Fausto. São Paulo: W. M. Jackson Inc., 1949.

NOGUEIRA, Carlos Roberto F. O Diabo no imaginário cristão. São Paulo, Ática, 1986.

PLATÃO. A República. São Paulo: Nova Cultural, 1999.

ROSA, Guimarães. Grande sertão: Veredas. Rio de Janeiro: Nova Fronteira, 2001.

\section{Imagem}

Disponível em http://1.bp.blogspot.com/_J9VoWoDbxps/R1GGq1fiwLI/ AAAAAAAAAEg/frLSHoymPpg/s1600-R/solto+na+rua3.jpg. Consultado em 07/10/2012. 